\title{
THE USE OF CONTENT-BASED SUMMARIZING TECHNIQUE IN IMPROVING STUDENTS' READING SKILLS OF MADRASAH
}

\author{
Zana Chobita Aratusa \\ Tadulako University, Indonesia \\ (zanaaratusa@gmail.com)
}

Received: $12^{\text {th }}$ October 2017; Revised: $22^{\text {th }}$ November 2017; Accepted: $27^{\text {th }}$ December 2017

\section{ABSTRACT}

Previous studies argued that summarizing techniques can improve students skill to comprehend a reading text, but those studies did not address what type of summarizing teachniques and how to apply them, in particular in Islamic schools context in which their studdents often study rich textual documents. Through the use of the experimental method, this study implemented Content-Based Summarizing Technique (CBST) in teaching English reading skill at two State Islamic Senior High Schools (Madrasah Aliyah Negeri) in Palu, Central Sulawesi. After 12 weeks teaching, this study found that students who were taught by using CBST have significantly improved their reading skill to comprehend a reading text. Meanwhile, the non-CBST treatment students' reading skill remain stable. This study concludes that the use of CBST in English reading teaching can be used as a new alternative technique in English teaching. The limitation of this study is that the treatment might not be long enough and the sample small. Future research need to involve more sample and apply longer treatment period.

Key Words: reading skill; content-based; reading technique; experiment

\begin{abstract}
ABSTRAK
Sejumlah penelitian sebelumnya menemukan bahwa teknik merangkum dapat meningkatkan keterampilan siswa untuk memahami teks bacaan, namun penelitian tersebut tidak membahas jenis pengajaran yang meringkas dan bagaimana menerapkannya, khususnya dalam konteks sekolah Islam seperti madrasah yang para siswanya sering mempelajari berbagai teks bacaan. Dengan menggunakan metode eksperimen, penelitian ini menerapkan Content-Based Summarizing Technique (CBST) dalam pembelajaran keterampilan membaca dalam bahasa Inggris pada dua Madrasah Aliyah Negeri di Palu, Sulawesi Tengah. Setelah 12 minggu mengajar, penelitian ini menemukan bahwa siswa yang diajar dengan CBST mampu meningkatkan kemampuan membaca mereka secara signifikan dalam memahami teks bacaan dalam bahasa Inggris. Sementara itu, kemampuan membaca siswa yang tidak diajarkan dengan -CBST tetap tidak meningkat. Penelitian ini menyimpulkan bahwa penggunaan CBST dalam pengajaran membaca bahasa Inggris dapat digunakan sebagai teknik alternatif baru dalam pengajaran bahasa Inggris. Keterbatasan penelitian ini adalah lamanya penerapan CBST mungkin tidak cukup dan sampelnya kecil. Penelitian selanjutnya perlu melibatkan lebih banyak sampel dan periode penerapan CBST perlu lebih lama.
\end{abstract}

Kata Kunci: ketrampilan membaca; content-based; teknik membaca

How to Cite: Aratusa, Z. C. (2017). The Use of Content-Based Summarizing Technique in Improving Students' Reading Skills of Madrasah. IJEE (Indonesian Journal of English Education), 4(2), 208-220. doi:10.15408/ijee.v4i2.6153 


\section{INTRODUCTION}

Reading skill is one of an important skill to be mastered by students in the English language teaching curriculum (Ronan, 2015). Most high school students have problems in reading various texts in English textbooks because they lack the specific strategies (Chen \& Sabina Chia-Li, 2015). Whereas in the English language textbook for high schools, in particular, Islamic senior high schools, there are many reading texts that require skills and good reading techniques to capture essential information. The lacks of students' reading skills make them reluctant to read English-text books. In addition, poor reading techniques also cause poor comprehension (Kispal, 2008) and also experience difficulties in many English exams such as semester and national examinations.

The success of reading skill teaching is highly dependent on the reading teaching techniques used by the teachers (Hermida, 2009). There are various techniques that have been applied by teachers in teaching English reading in High Schools, one of which is the technique of summarizing the reading content. Summarizing technique itself has been long enough applied in teaching reading skills and it has become a tradition that is used continuously by English teachers
(Cahyono, 1996; Cahyono \& Widiati, 2006) .

A traditional reading technique that is commonly used in summarizing is "précis." The approach used in the "précis" is called the text reduction approach (Cranmer, 1989). However, this approach does not provide students with good skills because the reduction of text content often results in the loss of main ideas in the text. As a result, this approach does not provide a good understanding of the issues developed in a reading text for students. Besides, this technique is not able to provide a clear guide to what to write (content) and how to write it (form) (Chambers \& Brigham, 1989).

The new direction of teaching reading skills in English emphasizes on understanding the content only (Monopoli, 2014). In other words, providing reading skills with emphasis on understanding the message in the text is better than understanding every word (Harmer, 2001). One of the reading techniques that provide skills to capture the content of the subject is Content-Based Summarizing (CBST) which is a technique of summarizing a reading text based on the main contents of the text (Cahyono, 1996). With this technique, the readers will get a picture of their understanding of the reading 
content (Anderson \& Hidi, 1988; Rivers, 1987).

Although the CBST is considered to be better at providing effective reading skills for English students, the application of this reading technique at the secondary school level is rarely performed and has not yet been determined to be effective. This requires a study of this technique by piloting the application of the CBST in teaching English reading skills to find a suitable teaching technique in reading skills development for high school students. In particular, Islamic school students often study rich textual textual documents such as Islamic history and teaching (Mcdonald, 2014).

The researcher expected that the use of content-based summarizing techniques (CBST) to Islamic senior high school students can improve their reading comprehension and summarizing ability. Moreover, it can have positive effects on the students to face the rich reading texts in their future studies. In this study, the researcher develops a hypothesis as follows; "Teaching reading comprehension with CBST significantly improve students reading comprehension skill".

\section{Summarizing Techniques}

For more than a quarter of a century, reading skills by English teaching experts are considered as one of the most important skills everyone should have. One of the important reading skills possessed is the skill of concluding a reading text. Joseph, et al., (2016), for example, assert that a teacher should help students develop their reading skills primarily by making a summary of the main idea of a paragraph in a text. The summary includes important ideas in a paragraph.

The summarizing technique is able to facilitate students in improving reading comprehension with a focus on meaning (Chastain, 1988). The reading comprehension is better when the students also involve self-questioning during reading to monitor their reading comprehension and increases their ability to learn independently (Joseph, et al., 2016). The ability to be independent in reading can help teachers to reduce their role in a reading class session.

The summarizing technique referred to in this study differs from the technique of summarizing in the traditional sense. In the traditional sense, the summarizing technique is often understood as the way to reduce a reading text becomes as short as 
possible. However, the summarizing technique in this study is understood as content-based summarizing which is summarizing based on the meaning or content of a reading text. This summarizing technique is able to improve students comprehension and their summaries skill especially in cases of finding the main ideas, committing plagiarism and committing distortion (Khathayut \& Karavi, 2011)

To distinguish between contentbased summarizing technique with summarizing technique in the traditional perspective, Duke and Pearson (2002) have developed a procedure to guide students in summarizing a reading text. The procedure includes several steps such as; read skimming text, make a list of key points in the text, incorporate some interrelated points in a new statement, revise the key points, then re-read the list of key points, list the points and put them in order, lastly write these points in the form of paragraphs in sequence.

$$
\text { Meanwhile, Hayes }
$$
introduces a class procedure in teaching students how to write a summary of a reading text. The procedure is called the Guide Reading and Summarizing Procedure or (GRASP). The procedure is practiced in four stages as follows: 1) Prepare the students to start learning; 2) Have students to read the main point;
3) Help students group the main point of the subject in the text; 4) Show students how to turn these main points into a good summary.

Carnie, Sailbert, and Kameenui (2004) also introduce a summary technique which resembles contentbased summarizing. The summarizing technique is called the one sentence summary. The teaching procedure of this technique includes several steps: (1). A teacher tells the students how to write the main idea, (2). The students read the reading text, (3). The teacher asks the student to mark the main sentence along with the main idea in the sentence, (4). The teacher asks the students to mention the sentencem (5). The teacher repeats the steps by working on the rest of the existing text, (6). Finally the teacher asks the students to write the main idea for each paragraph.

Another summarizing technique is proposed by Chambers and Brigham (1989), which is called as the deletion approach to summarizing. This approach improves the traditional approach to summarize in the traditional perspectives which emphasize on the selection of the main idea in a reading text. Meanwhile, this deletion approach emphasizes on retrieval of the original text and removes only unimportant sentences, clauses, phrases 
or words until only the essentials remain.

The process of deletion requires five steps; (1). After reading, delete sentences that are just an explanation of the main sentence, (2). From the remaining sentence, then remove all unnecessary clauses and phrases, (3). Then from the remaining ones, remove again the less necessary, (4). Next replace the words left with the students' own words, (5). Lastly, write back the summary.

\section{CONTENT-BASED SUMMARIZING TECHNIQUE (CBST)}

The summarizing technique based on the Content Based Summarizing Technique (CBST) itself is a technique of summarizing a reading text based on the content of a discourse. This model is applied based on two assumptions; firstly, a good learning skill model is a model that can summarize the past and the present and also predict the future (Rivers, 1987), the second is that the summarizing activity of the students must reflect their understanding against a reading text (O'Dell, 1987).

In the summarizing process, some information should be included and some to be discarded. The main question is which information should be included in the summary and which is not. According to O'Dell (O'Dell, 1987), the most important thing in a reading activity is that students are able to understand the general meaning of the text they read, and then they have the ability to choose a little more specific information which is considered important.

Hennings (1991) argues that the ability of students to find the main idea is the most important skill. In this case, the main focus of teaching reading is to help readers find significant ideas in a reading text. However, teachers should understand that a student will not have the ability to read and understand content-based text if the teachers themselves are lacking on a contentbased reading strategy skills (Ronan, 2016).

Based on above argument, the CBST emphasizes on understanding the main idea of a reading text and this main idea must be summarized. Thus, CBST develops an assumption that the comprehension of a reading text can be obtained through the understanding of the main idea contained in the text itself. In this case, the main idea refers to a statement that circumscribed a paragraph (Afflerbach, 1990; Stevens, Slavin, \& Famish, 1991). The main idea is not merely a topic sentence, but it includes subject lines as well as ideas in the supporting sentences. The 
procedure of implementing CBST consists of three steps: 1) Students read a passage of text; 2) Students then make notes which include the main idea and if necessary also include the supporting ideas; 3) The final step creates a summary based on the note.

The procedures implemented in CBST provide an opportunity for students to grasp main ideas directly during reading activities. This CBST ensures that students are able to understand the contents of a text. The CBST also does not require students to pay attention to the text in detail because students' reliance on observing the text in detail will reduce students' ability to understand the content of the text itself. This is due to the fact that what students can remember longer is the general elements, rather than more specific information. If the main idea had been understood and remembered, then the details of the text itself can also be remembered because it is included in the main idea (Hayes, 1989).

Furthermore, CBST does not require students to identify the characters in the text and then tell what the characters do, because such strategy will prevent students from grasping the main idea in the text. This is because most of reading texts cannot be summarized by referring to the characters in it and what the characters do. Instead students are required to comprehend and experience a reading text (Duke \& Pearson, 2002). In addition, the CBST also does not require students to work in groups or spouses to produce a summary. The other specialty of this CBST is simply because it does not require a number of detailed steps before starting the reading. CBST instead directed students to get the main idea quickly after reading activities through quick a text scanning (Chambers \& Brigham, 1989).

In the application of CBST, teachers should choose the material content in accordance with the English proficiency of the students (Augusto-Navarro, 2015). Teachers can also provide a lower-level reading text than their current class. For example, if students sit in year two then it could be a reading material designed for first-year students to avoid difficulties in syntax and semantics (Brown, 2007).

\section{METHODS}

This study applied an experimental method, pretest-posttest control group research design (Kılıçkaya, 2011; Thomson, 2011). Two classes of the eleventh-grade students of two Madrasah Aliyah Negeri in Palu were recruited. One class with 20 students 
will be used as a treatment class. Meanwhile, another class with also 19 students will be functioned as a controlled class. The school has seven classes of grade seventh students, but only two classes will be randomly selected for this study.

On the first meeting, an informed consent form will be signed by the students agreeing to participate in this study. After the students signed the form, the teacher (the author herself) administered the pre-test. One class (controlled group) followed the traditional reading instruction technique and was taught by a usual teacher, another class (experimental group) followed CBST instruction.

The treatment with CBST was given for 12 weeks (about three months) with 90 minutes duration each meeting. The treatment class was taught by the researcher herself but all the teaching material was consulted with the schools English teachers to maintain validity. Meanwhile, the nontreatment classes were taught as usual by English teachers from the schools. Prior to the treatment, a pre-test was given to experimental and controlled classes within both schools. After the treatment was completed in 12 weeks, a post-test was given again to find the students' reading skill progress.

\section{Teaching Procedures}

Similar material was given to both experimental class and controlled class, but the experimental class was taught with CBST while the controlled class was taught with usual techniques used by English teachers in the schools. In this section, the author describes the process of CBST implementation in teaching a reading comprehension text. An example of a reading text was taken from "English for Islamic Studies" book with the title "Dwan of Islam" by Djamaluddin Darwis (1995, p. 88).

The application of CBST in the classroom was carried out in several stages. By reading the text, it is expected that students can make a summary based on the content of the text. In doing so, the students were assisted and directed by their teacher. An example of a teaching procedure is described in the following text. Similar procedures are also applied to other material used in this study.

\section{DAWN OF ISLAM}

In the beginning of Islam, Muhammad, the messenger, delivered his message to his family as well as to the quraysh people. With much struggle and unmatched patience Muhammad managed to collect a few followers. Muhammad talked to people and advised them not to worship the idols which were 
made of stone and which could neither do them any good not bring them any harm. He called them instead to follow the religion of Abraham: to believe in one God, Allah, and worship only him.

But non-believers went to believing in the idols and refused to accept Islam. They were afraid that Islam would bring them lots of enemies and make the rest of the Arabs hate them and boycott their trade. If that happened, they would be in great trouble. Therefore, they decided to do something to Muhammad and his followers. They agreed to send a delegation to Abu Thalig and asked him to settle this matter once and for all.

The spokesman said; "Look Abu Talib, you are one of our leaders, we greatly honour you. Will you judge between us and your nephew? Tell him to stop insulting our Gods, the Idols, mocking our religions, criticizing our beliefs and slandering our father who taught us these beliefs. Either you stop him or let us deal with him."

Abu Talib gave them no answer, but instead sent someone to look for the prophet and tell him to go to his uncle's house. When the prophet arrived he saw all the important Quraysh men gathered in his uncle's house. As soon as he got there, his uncle, Abu Talib, said to him, "My dear nephew, these are the heads of your people and the rich Quraysh men wishing to make a deal with you. They want you to stop attacking their gods, the idols and they will let you worship your God."

The prophet replied, "Can I call upon them to worship somebody else who is better than these idols?" "Who is that, son" "asked Abu Talib. " I would call upon them to say one little phrase. If they say it the rest of the Arabs will submit to them and they will rule the people of the world. All want them to say is "There is no God but Allah."

Based on the text above, the students are required to make a summary of three parts of the text. The first part of the text (paragraph 1) is about the Prophet Muhammad who began the dissemination of his teachings to his family and began to gather some followers. The second part is a summary consisting of paragraphs 2 to 4 , and the third section is paragraph 5. The summary of the text is as follows: Paragraph 1; Muhammad started to spread his message to his family and began to collect a few followers. Paragraph 2: It is about nonbelievers who were afraid of Islam. Paragraph 3: one of the non-believer asked Abu Talib to stop Muhammad's activities. Paragraph 4: Abu Talib tried to persuade Muhammad to stop his 
activities. Paragraph 5: It is about the strength of Muhammad's belief.

From the text above, the students, then, made notes in the form of the outline as follows:

- Personality : bright, patience, strength

- Activities : Delivered Islam messages to his family and Quraysh people

Activity in spreading Islamic teaching :

- Activities : Muhammad collect followers and talked and advised non believers.

- Reaction : Non-believers refused Islam and tried to persuade Muhammad

- Impact : Muhammad did not want to stop his activities to spread Islam message.

The writer judgment (Students): There is a combination of patience and faithfulness in Prophet Muhammad. He cannot be persuaded by non-Muslims with the wealth to stop his activities.

From the outline above, a final summary was made as follows:

\section{DAWN OF ISLAM}

According to the writer, Muhammad is a strong, patience, and loyal man. His activity at the beginning of Islam was to deliver message to his family and Quraysh people and collect followers. Then, he collected followers and advised nonbelievers to accept Islam. The reaction of non-believers was they refused Islam and tried to persuade Muhammad, but Muhammad did not stop to spread Islam message.

\section{RESULTS AND DISCUSSION}

In general, the average ability of students reading in English in MA Negeri I Palu and MA Negeri 2 Model Palu is almost similar. This was shown in the mean score obtained by the students of both schools when the initial test given. However, the average ability of the students of MA Negeri 2 Model Palu before the treatment was found to be slightly better, which the average initial score of the treatment class students is 46.25 and the average score of the class without treatment is 50.75. While the average initial score of the treatment class in MA Negeri I Palu is 43.3 and the average score of non treatment class without treatment is 49.52 .

Although the difference of mean score between two schools is not significant, this slight difference in score indicates that the ability of MA Negeri 2 Model Palu students in reading is better compared with the ability of MA Negeri I Palu students. 
The differences affected the ability of students to receive treatment material provided by researchers. This also affects the score of the final test of English reading skill.

The author gave post-test after 12 weeks ( one meeting each week) of the treatment material was given. The post-test results show the average score of MA Negeri 2 Model students is still better than MA Negeri 1 Palu for both treatment and non-treatment classes. The average score of the treatment class MA Negeri 2 Model is 61.00 and 51.5 for the controlled class. While the average score of treatment class MA Negeri 1 Palu is 54.05 and 51.19 for nontreatment class.

The result of statistical calculation of the test scores for both schools also shows that the calculation of "T-test" for each school is significantly difference between the treatment and non treatment class. The treatment class of MAN Model Palu produced "To" with 7.49 and the non-treatment class produced "To" with 0.76 which is significantly different. Furthermore, the treatment class of MAN 1 produced "To" with 8.36 and the non-treatment class produce "To" with 0.62 .

The resulting "T-test" is interpreted by taking into account "df" or "db". The number of "df" or "db" for MA State 1 Palu is N-1 $=21-1=20$, while "df" or "db" for State MA 2 Model Palu is N-1 = 20-1 = 19. "Df" or "db" of 20 and 19, after consulting with the " $t$ " Value Table, either at the $5 \%$ significance level or at a significance level of $1 \%$, it was found that the "t" or "T table" with critical value at a significance level of $5 \%$ is 2.09 for both schools. Meanwhile, when the significant level was reduced at $1 \%$, it was found that "Tt" was 2.86 for both schools.

By comparing the amount of " $t$ " obtained in the calculation (MA Negeri 1, 8.36 and MA Negeri 2 Model, 7.49) and the magnitude of " $\mathrm{t}$ " listed in $\mathrm{T}$ table $(5 \%=2.09$ and $1 \%=8.36$ and $7.49)$, it was found that the "To" is greater than " $\mathrm{Tt}$ " :

$\begin{array}{ll}\text { MA Negeri } 1 \text { Palu } & 2,09<8,36>2,84 \\ \text { MA Negeri } 2 \text { Model } & 2,09<7,49>2,86\end{array}$

Since "To" is greater than "Tt", the proposed Nil Hypothesis is rejected, which means that there is a difference in reading ability in English between before and after the use of ContentBased Summarizing (CBST) in teaching English reading skills. The statistics analysis show significant differences. In other words, the use of CBST in teaching reading skill within both schools has produced excellent results, comparing before the use of CBST.

Although the high level of reading skills is also closely related to the level 
of vocabulary mastery in English (Kameli \& Baki, 2013; Sidek \& Rahim, 2015), a proper reading technique use in a reading class greatly facilitates the fluency of reading and comprehension as found in this study. This study found that proper reading techniques really help students especially in achieving short-term goals such as answering questions test which is often conducted in limited time allocation. This technique helps students for future reading purposes such as the ability to read scientific texts in higher education institutions. Thus Content-Based Summarizing technique can be one alternative technique to improve English reading skill.

\section{CONCLUSION AND SUGGESTION}

This research has been carried out successfully, which finding shows that students' reading skill is improved after the use of Content-Based Summarizing (CBST) technique in teaching English reading. Some conclusions can be drawn from this research, among others: a) There is a significant difference in the score of English reading comprehension after the application of CBST in teaching reading. This is indicated by the value of "To" is 8.36 and 7.49 in MA Negeri 1 and MA Negeri 2 Model; b) The average reading comprehension final score of the students in both schools is significantly increased when compared to before treatment (from 43.3 to 54.05 in MA Negeri 1 and 46.25 to 61.00 in MA Negeri 2 Model). While the average score of students in non-applied CBST technique classes does not show significant progress in their reading skills; c) The average reading ability of students in MA Negeri 2 Model is better than MA Negeri 1 students. This is reflected in the average values obtained before the CBST was applied and after the implementation of the CBST. A similar result can also be seen in the mean score of students in nontreatment classes in both schools.

This study was carried out with scientific procedure, but the author acknowledges the limitation of this study. For example, the experimental session might not be longer enough, which is less than 14 weeks or four months. However, since the teaching procedure was apllied properly and according to the schools' guidelines and the material was also validated by the teachers at schools, the author believes the result can be used as a reffence in teaching reading comprehension successfully at schools.

Future research need to implement longer treatment period and with various reading material to produce more validity in research. More classes 
should also be involved to maintain the validity.

\section{REFERENCES}

Afflerbach, P. P. (1990). The Influence of Prior Knowledge on Expert Readers' Main Idea Construction Strategies. Reading Research Quarterly, 25(1), 3146.

Anderson, V., \& Hidi, S. (1988). Teaching Student to Summarize. Education Leadership, 46(4), 26-28.

Augusto-Navarro, E. H. (2015). The Design Of Teaching Materials As A Tool In Efl Teacher Education: Experiences Of A Brazilian Teacher Education Program. Ilha Desterro 68(1), 121-137.

Brown, C. L. (2007). Content Based ESL Curriculum and Academic Language Proficiency. Retrieved 20 October 2017, from The University of Tennessee http://iteslj.org/Techniques/BrownCBEC.html

Cahyono, B. Y. (1996). Development and application of content-based summarizing technique in reading instruction. Jurnal Ilmu Pendidikan, $3(1), 27-36$.

Cahyono, B. Y., \& Widiati, U. (2006). The Teaching Of Efl Reading In The Indonesian Context: The State Of The Art. TEFLIN, 17(1), 36-58.

Chambers, F., \& Brigham, A. (1989). Summary Writing: A Short Cut to Success. Forum Magazine 27(1), 45-50.

Chastain, K. (1988). Developing Second Language Skills: Theory and Practice (3 ed.). New York: Harcourt College Pub.
Chen, K. T.-C., \& Sabina Chia-Li, C. (2015). The Use of EFL Reading Strategies among High School Students in Taiwan. The Reading Matrix: An International Online Journal, 15(2), 156166.

Cranmer, D. (1989). Notes, Summaries and Composition. London: Edward Arnold.

Darwis, D. (1995). English for Islamic Studies. Jakarta: PT RajaGrafindo Persada.

Duke, N. K., \& Pearson, D. (2002). Effective Practices for Developing Reading Comprehension What Research Has to Say About Reading Instruction, (pp. 205 - 242). London: International Reading Association.

Harmer, J. (2001). The Practice of English Language Teaching. New York: Longman.

Hayes, D. A. (1989). Helping Students GRASP the Knack of Writing Summaries. Journal of Reading, 33(2), 96-101.

Hennings, D. G. (1991). Essential Reading: Targeting, Tracking, and Thinking about Main Ideas. Journal of Reading, 34(5), 346-353.

Hermida, J. (2009). The Importance of Teaching Academic Reading Skills in First-Year University Courses. The International Journal of Research and Review, 3, 20-30.

Joseph, L. M., Alber-Morgan, S., Cullen, J., \& Rouse, C. (2016). The Effects of Self-Questioning on Reading Comprehension: A Literature Review. Reading \& Writing Quarterly, 32(2), 152-173.

Kameli, S., \& Baki, R. B. (2013). The Impact of Vocabulary Knowledge Level on 
EFL Reading Comprehension. International Journal of Applied Linguistics E English Literature, 2(1), 5.

Khathayut, P., \& Karavi, P. (2011). Summarizing Techniques: The Effective Indicators of Reading Comprehension? Paper presented at the The 3rd International Conference on Humanities and Social Sciences, Bangkok.

Kılıçkaya, F. (2011). Improving Pronunciation via Accent Reduction and Text-to-speech Software. In M. Levy, F. Blin, C. B. Siskin \& O. Takeuchi (Eds.), WorldCALL: International Perspectives on ComputerAssisted Language Learning (pp. 85-96). New York: Routledge.

Kispal, A. (2008). Effective Teaching of Inference Skills for Reading (No. DCSFRR031). London: National Foundation for Educational Research.

Mcdonald, D. (2014). A Text Mining Analysis of Religious Texts. The Journal of Business Inquiry, 13(1), 2747.

Monopoli, M. (2014). Reading comprehension development in the English B lesson. Retrieved 15 September 2017, from St. Catherine's Moorland:

http://www.ibo.org/contentassets/ 4ccc99665bc04f3686957ee197c13855/e xecutive-summary-monopoli.pdf

O'Dell, F. (1987). English as a Foreign Language Prelimnary Examination. London: Longman.
Rivers, W. M. (1987). Interactive Language Teaching. London: Cambridge University Press.

Ronan, A. (2015). Why Reading Comprehension in the Content Areas is so Important. Retrieved 05 October 2017, from Edudemic: http://www.edudemic.com/reading -comprehension-content-areasimportant/

Ronan, A. (2016). Why Reading Comprehension in the Content Areas is so Important. Retrieved 20 October 2017, from Edudemic : Connecting Education and Technology: http://www.edudemic.com/reading -comprehension-content-areasimportant/

Sidek, H. M., \& Rahim, H. A. (2015). The Role of Vocabulary Knowledge in Reading Comprehension: A CrossLinguistic Study. Paper presented at the 7th World Conference on Educational Sciences, (WCES-2015), Athens, Greece.

Stevens, R. J., Slavin, R. E., \& Famish, A. M. (1991). The Effects of Cooperative Learning and Direct Instruction in Reading Comprehension Strategies on Main Idea Identification. Journal of Educational Psychology, 83(1), 8-16.

Thomson, R. I. (2011). Computer Assisted Pronunciation Training: Targeting Second Language Vowel Perception Improves Pronunciation. CALICO Journal, 28(3), 744-765. 